\title{
MIR181A2 wt Allele
}

National Cancer Institute

\section{Source}

National Cancer Institute. MIR181A2 wt Allele. NCI Thesaurus. Code C82121.

Human MIR181A2 wild-type allele is located in the vicinity of 9q33.3 and is 109 bases in

length. This allele, which encodes the MIR181A2 pre-miRNA, plays a role in the regulation

of gene expression. Alteration in the expression of this gene is associated with development of glioma and multiple myeloma. 